\title{
Shameful science: four decades of the German tobacco industry's hidden research on smoking and health
}

The following presents the "best of the best" of annotations of over 600 tobacco industry documents that tell a nearly 40 year story of the smoking and health research programme sponsored by the members of the Association of Cigarette Industries of Germany (the "Verband"). Its members include the German and Austrian cigarette manufacturers as well as the transnational firms of Philip Morris (PM), RJ Reynolds (RJR), and British American Tobacco (BAT).

The documents are part of some 33 million pages released as a result of legal agreements in the USA between state attorney generals and the American based tobacco companies. Virtually all are available on Internet websites. While nearly all the annotated documents come from PM and RJR and are in English, a large cache of BAT documents on the Verband are held at the BAT depository in Guildford, UK, including a group of German language documents. These are yet to be reviewed. Nonetheless, what is presented adequately highlights the astonishing story of corrupted science in the service of a deeply flawed product. The selected quotations will astonish even those who have become inured to what has already been discovered.

Beyond the petty squabbles and unpleasant characters, the story can be boiled down to a few essential themes.

The company scientists had to struggle with the accumulating and on-rushing evidence that theirs was one of the foulest products (in the environmental sense) sold to be taken into human bodies. That struggle was seldom openly or honestly fought.

Even as some of the scientists hoped, in vain, to create the "safer cigarette", company lawyers were focused entirely on avoiding litigation, and avoiding loss when sued. An army of public relations experts, front organisations, and corrupted consultants served the lawyers, not the truth-the companies, not the public.

German tobacco scientists, led by Professor Franz X Adlkofer, managed to integrate and ingratiate themselves with leading researchers, academics and government officials, even with some who were strongly anti-tobacco. This gave the German industry the prestige and time to carry out research, and the ability to influence policy in Germany and throughout Europe and other continents, even today.

German scientists knew from the start that the true battleground was, and still is, passive smoking. Their worry was not so much whether smoking caused disease - they knew early on it did-but they were obsessed by the evidence that tobacco poisons released into the air could affect the health of non-smokers; and they did everything they could to deny, suppress, and finally ignore the overwhelming evidence.

\section{The documents}

The Verband der Cigarettenindustrie $(\mathrm{VdC})$ is the German trade association of cigarette manufacturers whose members include the German and Austrian tobacco companies (Reemstma, Brinkmann, H van Landwyck, Austria Tabak, and three smaller companies), as well as the German branches of three transnational firms (PM, RJR, and BAT). It comprises five departments: industrial activities, trade issues, marketing, public affairs, and the scientific department. It is mainly the activities of the latter that are displayed in the industry documents.

The transnational firms felt it was necessary to support research in Germany, both through the Verband as well as through private grants to German scientists. A 23 July 1992 memo from one PM lawyer to another explains: "The relationship between the industry and the German government seems to be a good deal better than the relationship between the industry and the government in this country. As I understand it, there are regular consultations between government and industry scientists, as well as constructive discussions regarding smoking related laws and regulations. The industry in Germany appears to be more influential with the government than the industry in the US and, for that reason, the industry feels it is important to maintain a substantial research presence. Although I do not believe litigation is imminent in Germany, should it occur, the fact that we are sponsoring research-whether through the Verband, or individually - could be of substantial help, in convincing a court that we are fulfilling our duty to conduct research. Nor do I think we should downplay the importance of having scientific contacts in as important a country as Germany."1

It was also the case that "Throughout the domestic industry, two gentlemen's agreements operative in the early days" indicated that "any company discovering an innovation permitting the fabrication of an essentially safe cigarette would share the discovery with others in the industry", and that "no domestic company would use intact animals in-house in biomedical research". This alone would have prompted the major transnational firms to look 
to the VdC to sponsor such research in Germany. $^{2}$

An example of a "gentleman's agreement" is provided in this 1963 draft contract between the British tobacco industry and the Verband's research arm to share results pointing to a cigarette less likely to cause cancer, thus implicitly acknowledging the danger. "The Tobacco Research Council [UK] and the Wissenschaftliche Forschungsstelle agree by this contract to submit to each other without delay the following informations which have to include all technological details of manufacture. These are: (1) Information about modifications to cigarettes or other tobacco products which have been shown to be beneficial to human health. (2) Information about modifications to cigarettes or other tobacco products the smoke or smoke condensate of which have been shown to produce less biological activity to an extent that was statistically significant, (a) in a test (or tests) of a type that was relevant for lung cancer or other human diseases ... Both the Tobacco Research Council and the Wissenschaftliche Forschungsstelle respectively will endeavour to conclude equal contracts with AUSTRIA TABAKWERKE, Vienna . . . ADMINISTRAZIONE DEI MONOPOLI DI STATO, Rome . . . SERVICE D'EXPLOITATION INDUSTRIELLE DES TABACS ET DES ALLUMETTES, Paris . . . SVENSKA TOBAKS AKTIBOLAGET, Stockholm . . . VEREIGNIGTE TABAKFABRIKEN AG, Neuchatel."”3

But as this visit report (to industry laboratories in England, Sweden, Germany, France) describes, the rationale behind "smoking and health" research done by the Verband companies seemed as much for political advantage as for preventing disease. "[The Germans] have apparently convinced their Minister of Health that they know more about smoking and health than anyone else, that they are taking responsible actions, and he apparently turns to them for advice. The German companies seem to be working closely together, and have decided that no one can afford the luxury of a temporary competitive advantage in the smoking and health area. BAT, for example, has company supported research which shows that "KRONE", their newest brand, has $50 \%$ of the biological activity of other brands (based on mouse skin painting). They will not advertise this under any circumstance and presumably will make the processes used available to others when they are certain there is a health significance. They do not consider that they are in a vulnerable position because they are conducting mouse skin painting tests, but rather consider that this was essential in establishing their position with their Minister of Health. I consider the German industry to be in a better position than the industry of any other country, and hope that the US industry can move in that direction." 4

The relationship between the transnationals, $\mathrm{PM}$ and RJR in particular, and the Verband was fractious from the start because the
American companies' research effort from the 1950s on was driven by concern over law suits, and was therefore controlled by the company lawyers and law firms. Edwin Jacob of the law firm Jacob, Medinger was quite emphatic in a 1978 meeting with the leaders of the Verband research programme, Harold Koenig and Franz Adlkofer, as reported in a secret RJR memo: "Mr Jacob then proceeded to explain the dangers of nicotine research from the point of view of the Industry, with special reference to the threat of the American Industry being placed under the jurisdiction of the Food and Drug Administration . . . We then somewhat forcibly and-deliberately-overbearingly extracted from them an unequivocal promise that before any effort which was made to commence or in any other way start a specific research project, RJR-like the other member Companies of the Verband-would have a minimum of three months to evaluate each proposal . . Almost all of the meeting in London dealt with the legal perils and related aspects of the concepts on nicotine oriented research of the Verband." 5

The legal perils, as the transnational firms saw it, also extended to any research that might even remotely suggest that cigarettes were harmful. For instance, Franz Adlkofer was adamant over the decades that the Verband research be directed towards creating a "safer cigarette," and this led to continuous conflict, even up to the mid 1990s. "RJR has always rejected the idea of developing a "safe" cigarette being based on an unfounded assumption, to wit, current cigarettes are unsafe. Instead, RJR's position has always been, and still is, that cigarettes have not been scientifically established as disease producing in human smokers ..."

However, Adlkofer's notion of "safer" had a rather grim aspect: "Talking about 'the less harmful cigarette', [Adlkofer] said ... . this would most likely prolong the latency period for cancer by another 5-10 years, and thus would make it a no-issue for the cigarette industry."7

And in another account, an attorney from Jacob, Medinger, preparing a White Paper to instruct the Verband, contrasted RJR's position with Adlkofer's: " $[\mathrm{He}]$ believes that smoking is killing a couple of hundred thousand people a year and that his job is to cut that figure down to only 50,000 or so . . . [but] because of RJR Germany's share of market it did not have enough clout to remedy this situation ... The paper was drawn largely from materials which we and the US industry had used before in Congress and court."

The transnationals had another reason to keep supporting research in Germany: the desire to recruit expert "witnesses" who could be relied on to spread the tobacco industry views. One method was to invite scientists to a conference whose sponsorship would remain secret lest it "would preclude the ability to attract the participants desired". One such conference was a symposium on passive smoking "intended to establish witnesses, interna- 
tional sociologists, lawyers and scientists that the industry could count on in other areas". ${ }^{9}$

In public, the Verband followed the tobacco industry line, denying the overwhelming evidence that tobacco caused disease and death: "The Dusseldorf branch of the semi-official German Health Insurance, which insures about $70 \%$ of all West Germans, made the following false allegations: 1 . 'There is a cause and effect relationship between cigarette smoking and various diseases.' 2. 'Tobacco advertising induces children and young people to smoke.' 3. 'Smokers are insufficiently informed regarding the effect of smoking on health.' The Verband has replied over the signature of $\mathrm{Mr}$ von Specht regarding point 1 . That 'risk factors' are not synonymous with causation, and that relationships between smoking and health are a matter of controversy ... Regarding point 2, the Verband stated that not a single study backs up the insurance's claim ... Regarding point 3, it was pointed out that all press, radio and TV polls have come to contrary conclusions." ${ }^{10}$

But in private it was another matter: Colby quotes Adlkofer in a secret document as saying that "risk factors were more or less synonymous with causation". Colby relates further, "In the sum he believes that smoking 'causes' lung cancer, heart disease....". ${ }^{11}$

The Verband took it far beyond simply putting on a good face for the public. It actively suppressed its own research that demonstrated the damage cigarette smoke can do. The most egregious example came in 1975 with the total dismantling of the German Industry Research Institute, then headed by Professor Walter Dontenwill. Dontenwill created a cause celebre when he demonstrated that hamsters inhaling cigarette smoke came down with tumours of the larynx, some of them malignant, and cardiovascular disease; his paper was published in 1973 in the prestigious fournal of the National Cancer Institute. He had the further temerity to hold a press conference announcing the results. As told by the 1980 BBC Panorama programme, a secret Verband meeting pensioned off Professor Dontenwill, age 50, with DM1.6 million, the equivalent of 10 years salary. The Research Institute was replaced by an "independent" research funding agency, supported by the German and transnational cigarette industry, and used to approve research proposals coming from various scientists and institutions. As the chairman of the Verband, Dieter van Specht (BAT/ Germany) blandly explained: "The main motive reportedly was the fact that in matters of smoking and health, the Institute was the only 'porte-parole' of the Industry. Professor Dontenwill's uncooperative and authoritarian manner made it impossible for the VdC (and the Industry) to expose their views in these matters." ${ }^{12}$ Verband did not re-establish a separate laboratory for nearly a decade.

New research coming out of that laboratory in Munich was also susceptible to suppression if it showed results unfavourable to the industry. In Adlkofer's and Verband's desire to absolve nicotine generally (a "safer" cigarette would have a greater ratio of nicotine to tar), it was crucial to show that nicotine was not metabolised in the body to the cancer causing substances called nitrosamines (which, of course, ignored the substantial contribution of nitrosamines from the other components of tobacco). When it appeared that of 10 smokers none showed excretion of the toxin when injected with radioactive nicotine, a presentation at an international conference in Hawaii was prepared. When more careful analysis was done, four of the 10 showed positive results, and the responsible Verband researcher (Anthony Tricker) was forbidden to go to Hawaii. PM's Walter Fink worried that "The situation . . . is comparable with the situation under Dontenwill. Will the consequences be the same?" The Verband's science policy committee decided to present the original negative results and "project work terminated". ${ }^{13}$

The decision to withdraw the poster on nitrosation of nicotine at the nitrosamine meeting in Hawaii, when four persons dosed with radioactive nicotine were found to have nitrosamine in the urine "was subsequently reversed after repetition of the experiments had shown that endogenous nitrosation of nicotine can certainly be ruled out". ${ }^{14}$

In 1993 Stephen Hecht of Ernst Wynder's American Health Foundation showed that non-smokers exposed to heavy passive smoking absorbed nitrosamines in about the same ratio compared to smokers as the incidence of lung cancer between the two groups. Understandably, perhaps, the transnational firms were especially skittish about any further attempts to replicate the Hecht study. When Gerhard Scherer of the Verband's laboratory proposed an elaborate protocol to test passive smoking again, the Verband decision was firmly negative: "Unnecessary; not to be done!" ${ }^{15}$ RJR chemist David Doolittle advised Verband and RJR to do nothing about the Hecht study. After a vigorous attack on Adlkofer's scientific ability and claims that Verband had never shown hazardous effect of environmental tobacco smoke (ETS) on humans ("... none of these studies (as far as I know) have ever been accepted for publication in peer reviewed journals, and are virtually unknown in the scientific world"), Doolittle argued against doing any "real life" study (ETS exposure equivalent to what would be found in a cocktail lounge): "I think this study would not only be unhelpful, but would probably be uninterpretable and leave the door open for prohibitionists to interpret in a malicious manner. Therefore, I feel strongly that this study should not be done. There are only two possible outcomes from the NNAL and NNAL-glucuronide measurements - either you will find it, or you won't find it. If you do find it, all it does is confirm the American Health Foundation thesis that non-smokers are exposed to biologically relevant doses of NNK. We would not be able to put this into perspective in any way, nor be able to argue with any effectiveness that this level of exposure is biologically insignificant, since we have no data to support this position [emphasis 
added]. On the other hand, if we do not find the metabolites in the urine; there are only two possible interpretations. The first interpretation is the NNK has been metabolised by the non-smoker to active metabolites and is now bound to the individuals' DNA, RNA and protein. This obviously is an undesirable interpretation of the data. The other interpretation would be that the method is simply too insensitive to detect the metabolites at a low dose level."

Doolittle went on to describe the kind of study he would favour, one with predetermined outcomes: "In summary, in my mind the ideal would be to develop a data set which shows the following: First, people are exposed to very, very low levels of NNK in ETS. These data will likely be developed by other individuals, so the industry needs (at most) to only confirm these numbers with limited studies. Second, the small amount of NNK absorbed by individuals exposed to ETS is biologically insignificant for the following reasons: (1) it is effectively detoxified and excreted by the body; (2) the biological activity of NNK is inhibited by nicotine and cotinine which will always be present in gross excess relative to NNK, both in atmospheres and in the body; (3) the level of nitrosamines received by an individual following ETS exposure is insignificant compared to nitrosamine exposures from other sources, such as food." 16

Nonetheless, somehow, the experiment was done by the Verband, and the results were virtually the same as Hecht's: "Some time ago, the Munich Laboratory of the Verband conducted a study to investigate the uptake of NNK by smokers and non-smokers. Regarding non-smokers exposed to ETS, the analytical data indicated that they were exposed to about $1 \%$ of a smoker's average NNK dose. No steps were taken at that time to communicate these results externally or to publish them.." ${ }^{17}$ [emphasis added] This study indeed has yet to appear in any peer reviewed journal as of January 2000.

The Verband recognised long before the transnationals that the real battleground would be over passive smoking. The industry always argues that smoking is an individual choice and smokers know the risks. If it could be shown that non-smokers are involuntarily at risk, then smoking becomes a more unacceptable behaviour, regulation increases, and sales go down. In 1980, Hirayama in Japan and Trichopoulos in Greece showed that non-smoking wives with lung cancer were more likely to have lived with smoking husbands, with the correlation stronger the longer and more intense the exposure. The tobacco industry went on the attack almost immediately, one which has not let up until today even though the best designed studies continue to demonstrate the same effect (not to mention the proven ill effects in children and other susceptible persons). In private, however, Adlkofer and his colleagues concluded that Hirayama was right, and it was up to the Verband to find a "threshold" limit of still safe exposure: "Dr Adlkofer . . . has committed himself to the position that [indus- try statistician] Lee and Hirayama are correct and Mantel and TI [Tobacco Institute] are wrong. They believe Hirayama is a good scientist and that his non-smoking wives publication was correct . . . Adlkofer [said] that the TI knew it and that TI published its statement about Hirayama knowing the work was correct." 18

The threat was considered so serious that for the next two decades the tobacco industry recruited expert consultants, set up or subsidised front groups, and staged conferences to cast doubt that passive smoke was anything more than a nuisance. Only since industry documents have become public do we know that the consultants and conferences were being secretly supported by the tobacco companies through their law firms and public relations companies. The Verband was enlisted in this global effort. Whatever was said in private meetings, Verband played a loyal role vis a vis the entire industry in its public relations campaigns, whether on taxation, health warnings, harassment of anti-smoking groups, cultivating journalists and government officials, impugning the work and character of researchers finding harm in cigarettes, and creating citizen front groups from industry employees: "Therefore, the Verband jointly with the Tobacco Workers' Union holds regular smoking and health lessons where employees of the different member companies are taught the basic issues and how to defend industry's positions ... Today the Verband disposes of a network of more than 200 employees all over the Federal Republic. They keep us informed about their local media scenery and they write letters to the editor, if necessary. It is planned to organise and structure this PR force in a way comparable to the American Tobacco Institute's TAN [Tobacco Action Network] with similar tasks and responsibilities."19

It was precisely in the public relations efforts that Verband was so valuable to the transnationals. As PM attorney Charles Wall wrote to PM attorney Murray Bring, "The industry in Germany appears to be more influential with the government than the industry in the US". ${ }^{20}$

One egregious example suffices to demonstrate that influence. Professor K Ueberla was president of the Federal Health Office in Berlin and thus in an influential position to determine policies on tobacco, both in Germany and within Europe. In September 1982, Ueberla was given a Verband grant to do a field study on passive smoking, for as Adlkofer remarked, he "was totally convinced that the attitude of Professor Ueberla was positive towards passive smoking". ${ }^{21}$ A year later, as Adlkofer told an audience of the National Manufacturers Association in Washington DC, the dangerous findings of Hirayama and Trichopolous were neutralised: "So industry by its research branch engaged itself in a research programme on passive smoking done by the highest health authority in Germany, which is the Federal Health Office in Berlin. This cooperation, though rather new, is bearing already some fruit. In a recent statement on passive smoking 
in the Hessian Parliament the Hessian State Government cited from a letter of the Federal Health Office to the Federal Health Ministry. It said that inspite [sic] of the findings of HIRAYAMA and TRICHOPOULOS there is not sufficient evidence to support the assumption that passive smoking causes lung cancer in non-smokers." 22

The Verband maintained good relations even with the pioneer smoking and health researcher, the late Ernst Wynder, in particular because Wynder honestly believed that passive smoking did not cause lung cancer (his own hospital based case control study was negative). Franz Adlkofer's budget projection for $\mathrm{VdC}$ and the Forschungsrat research for 1982-85 contained this item: "Cooperation with Professor Wynder. Adlkofer recommended continuous cooperation and stressed Wynder's pro-industry attitude vis-a-vis public smoking. Because of his expertise Wynder shall be paid US $\$ 100000$ for another year as VdC consultant." 23

Professor Ueberla was helpful in another matter as well. The cigarette flavouring additive, coumarin, had been shown to cause liver damage and cancer in animals, yet the Verband was seeking to not have it banned in German cigarettes. Adlkofer admitted that "It could not be excluded that the majority of animals had cholangiofibroses, only, but a small number of animals had cholangiocarcinoma". Nonetheless, President Ueberla of the Federal Department of Health said he would postpone a final decision on coumarin until all the data were in, and "would not consider cholangiofibroses a major obstacle for an official permit to use coumarin as additive for tobacco products." 24

The Verband continued to demonstrate its commitment to the global industry. In 1989, PM International launched its "Boca Raton Action Plan" (so-named for the city in Florida where PMI's top executives met), initiating a wide ranging series of strategies to counter the anti-smoking movement, and targeting the World Health Organization in particular. The "Plan" generated much activity around the world, and not only by PM affiliates. A PM/Germany employee reported back to his superiors on what the Verband was doing to hold up its end of the work in Germany. "The VDC sends scientists to the various scientific conferences amongst others recently the "Therapie Woche" (therapy week) in Karlsruhe for German specialists in internal medicine. One topic at the Therapie Woche was 'Passive smoking and its effects on health'. The conclusion of the discussion was that the majority of scientists agreed that passive smoking cannot be classified as a health risk . . The German airline Lufthansa has introduced a test smoking ban on two short circuit flights (40 to 50 minutes flying time) national flights. The VDC has an actionplan [sic] to counter this Lufthansa activity . . . At the present there are only about 1000 restaurants in Germany which have nonsmoking areas ... The VDC works with the DEHOGA (German Association of Hotels and Restaurants). The DEHOGA is against divisions in restaurants for specific nonsmoking sections. The VDC is preparing a brochure at the present to send to the restaurant owners ... One smokers rights group in Germany is quite promissing [sic] at the moment. The "Raucher wehrt Euch" (smokers defend yourselves) RAWE who fight for smokers rights. VDC assists this association which is having its first successfull [sic] publications also successfull press and television appearances ..."25

\section{Envoi}

This report, highlighting the "best of the best" documents, may serve as a baseline mark to measure what the German cigarette industry and its collaborators will do in this new millennium, with respect to research, revelation, and honest dealings with the community of Europe. In the latest documents to be uncovered we read the following:

"The exhaustive publication of all types of $\mathrm{VdC}$ documents on the Internet by US tobacco companies created a violation of personal rights of some of the academic researchers sponsored by the VdC. A task force within the $\mathrm{VdC}$ is preparing a complete report on the types of Internet documents, their importance, and their interrelation to each other. In order to avoid similar actions in the future, several options for the internal VdC correspondence and information of member companies will be tested."

In a subsequent meeting, the activities of the $\mathrm{VdC}$ in the analysis of GM [genetically modified] tobacco were discussed. ${ }^{26}$

Minneapolis, Minnesota, USA

NORBERT HIRSCHHORN

hirsc024@tc.umn.ed

Support was provided by the Tobacco Free Initiative of the World Health Organization

1 "Philip Morris Research". PM 2022850392-0402, at www.tobaccodocuments.org

21983 memo by RJR senior scientist Alan Rodgman and Associate Director Frank Colby, "Smoking and health Associate Director Frank Colby, "Smoking and health
related research conducted by Philip Morris," displayed on 17 December 1997, deposition of Frank G Colby "In The Matter of State of Minnesota, et al. V. Philip Morris, et al," Matter of State
pages $54-5$.

3 1 April 1963, "Draft International Agreement on Exchange of Information ... [between] the Tobacco Research Council on behalf of its member companies, and the Wissenschaftliche Forschungsstelle im Verband der Cigaretten-Industrie on behalf of its member companies," BAT (File no. B4908) 10536891-8919 (located in the Minnesota Tobacco Depository)

419 July 1966, trip report, RB Griffith (Brown and Williamson researcher) to A Yeaman (B\&W in-house counsel)
RJR 680204107-4114, at www.tobaccodocuments.org

515 October 1978, Frank Colby, "Discussions with the Verband on their suggested nicotine research concepts." RJR 503247193, 503247196, 503247198,503247200-7210, at 503247193, 503247196, 50324
www.tobaccodocuments.org

6 Mid-1970s report by Frank Colby, RJR 500924982-5003, at www.tobaccodocuments.org.

71 July 1982, Bernd Pelz, RJR/Germany, "Meeting with Dr. Adlkofer ... to discuss the Verband research philosophy, and other issues that have caused friction between the Verband and RJR on matters of smoking and health-related research," RJR 500534225-4228, at www.tobaccodocuments.org

812 March 1983, T Finnegan, RJR 505745870, at www.tobaccodocuments.org

928 November 1979, Richard Marcotullio, "ICOSI International Public Smoking Symposium". RJR 5021227922797, at www.tobaccodocuments.org

1014 January 1980, Frank Colby, "False allegations made by German semi-official Health Insurance.” RJR 502856873, at www.tobaccodocuments.org 
116 March 1980, Colby, " Re: Meeting with Dr Adlkofer, March 6, 1980 in Houston, TX.” RJR 511468214-8215, March 6, 1980 in Houston, TX"

122 June 1976, Max Hausermann (PM/Germany), "Germany: VdC meeting on the Research Council," PM 1000122983-2985.

131 October 1991, Robert Pages, "WPA meeting of September 26, 1991," PM 2023222878-2880, at www.tobaccodocuments.org

1430 January 1992, minutes, Walter Fink to Manuel Bourlas (Director R\&D, PM/Neuchatel), "VdC WPA", PM 2050803525-3528.

1517 March 1994, PM 2028361491.

168 March 1994, trip report, David Doolittle, "Report on BESSE (biological effects of sidestream smoke exposure) meeting," RJR 508812179-2183.

1714 October 1997, memo, Lutz Mueller, "NNK metabolites in non-smokers," RJR 517623502-3503.

1824 July 1981, JK Wells (Brown and Williamson counsel) "Interesting developments on the Hirayama matter," BW "Interesting developments on the Hirayama matter," BW ments.org
199 October 1981, report from Verband, "Confidential PR-Status Report 1981 Smoking Issues in Germany," BAT 109869093-9112, from the BAT Guildford, England Depository, at www.cctc.ca/ncth/guildford

2023 July 1992, "Philip Morris Research," PM $2022850392-$ 0402 , at www.tobaccodocuments.org

21 RJR 501014852-4855, at www.tobaccodocuments.org

2220 September 1983, Professor Adlkofer's speech, "Passive smoking, presentation by the Verband der Cigaretteindustrie," PM 2501021630-1639.

2315 July 1982, meeting notes, VdC TFA, Oscar Stuhl (RJR/ Germany) to Wilfried Dembach (RJR/Germany attorney), RJR 501545528-5533, at www.tobaccodocuments.org

2418 August 1982, meeting notes VdC TFA, Stuhl to Dembach, RJR 501014963-4967, at www.tobaccodocuments.org

2510 October 1989, Ferdi Breidbach, "Boca Raton Progress Report,” PM 2500019912-9913.

2624 September 1998, "Meeting of the Scientific Commission (WPA) of the German Cigarette Association (VDC).” PM 2063664420

The material presented in this article is drawn from documents found on industry websites and in the Minnesota Tobacco Document Depository (unless otherwise noted), and represents in narrative form a selection from over 600 annotated documents posted ment Depository (unless otherwise noted), and represents in narrative form a selection from over 600 annotated documents posted
to the restricted email list Globalink in September 1999 and April 2000. The article has been published on the web previously. 